\title{
Mercury in benthic invertebrates of the Elbe estuary
}

\author{
G.-P. Zauke \\ Institut für Hydrobiologie und Fischereiwissenschaft, Universität Hamburg; \\ Hamburg, Federal Republic of Germany
}

\begin{abstract}
Hg}$ concentrations in benthic invertebrates of the Elbe estuary were analyzed by atomic absorption spectrophotometry and instrumental neutron activation analysis. In general $\mathrm{Hg}$ levels in organisms decreased from the limnic region to the marine environment. Highest $\mathrm{Hg}$ levels were found in Asellus aquaticus and Radix baltbica taken from the Elbe upstream of Hamburg ( 0.35 and $0.34 \mathrm{ppm}$ wet weight). The concentrations in gammarid species decreased from $0.20 \mathrm{ppm}$ (limnic region) to $0.02-0.05 \mathrm{ppm}$ (brackish and marine environment). $\mathrm{Hg}$ levels in organisms from the brackish region proved to be $0.08-0.16 \mathrm{ppm}$ (Littorina littorea), $0.04-0.09$ (Crangon crangon) $0.05-0.10$ (Corophium volutator) and $0.04-0.08$ $\mathrm{ppm}$ (wet weight) (Nereis diversicolor). Some factors which may influence the heavy metal concentrations in aquatic organisms are discussed, such as: food chain, weight of organisms, and elimination via moulting products in the case of crustaceans.
\end{abstract}

\section{INTRODUCTION}

Information about heavy metal contamination in the estuary of the River Elbe is available in papers of Nauke (1974; sediments and suspended matter), Müller \& Förstner (1975; clay fractions of the sediments), Harms (1974; fish) and Karbe et al. (1975). In general, relatively high values for several elements (including $\mathrm{Hg}$ ) were reported in the region upstream of Hamburg with a marked tendency to decrease in the region downstream of Hamburg.

Information on the degree to which natural populations of benthic invertebrates in the Elbe estuary are contaminated by heavy metals is still missing. The present study represents an attempt to establish the current level of $\mathrm{Hg}$ in naturally occurring populations of invertebrates and to discuss some factors which may influence $\mathrm{Hg}$ concentrations in these organisms.

\section{AREA AND ORGANISMS STUDIED}

The investigation was carried out in the estuary of the Elbe, concentrating on the brackish-water region; salinities ranged from 5-18\% (according to the "VeniceSystem"; cf. Caspers, 1959). A characterization of the localities is summarized in Table 1; their geographical position is shown in Figure 3. A summary of organisms 
Table 1

Locations of the sampling stations in the Elbe estuary (see Fig. 3)

\begin{tabular}{|ccll|}
\hline Station & River $(\mathrm{km})$ & Region & Locality \\
Oberelbe & $\begin{array}{c}\text { upstream of } \\
\text { Hamburg }\end{array}$ & limnic & Hitzacker- \\
1 & 643 & limnic & Hamburg \\
2 & 645 & limnic & Hamburg/Wedel \\
3 & 665 & limnic & Haseldorfer Marsch \\
4 & 709 & brackish & Bclumarztonnensand \\
5 & 712 & brackish & Otterndorf \\
6 & 720 & brackish & Altenbruch \\
7 & 725 & bradkish & Cuxhaven/Alte Liebe \\
8 & 727 & marine & Cuxhaven/Kugelbakc \\
9 & - & marine & Trischendamm \\
\hline
\end{tabular}

collected during spring (May), summer (July-September) and autumn (October till November) of the year 1974 is given in Table 2.

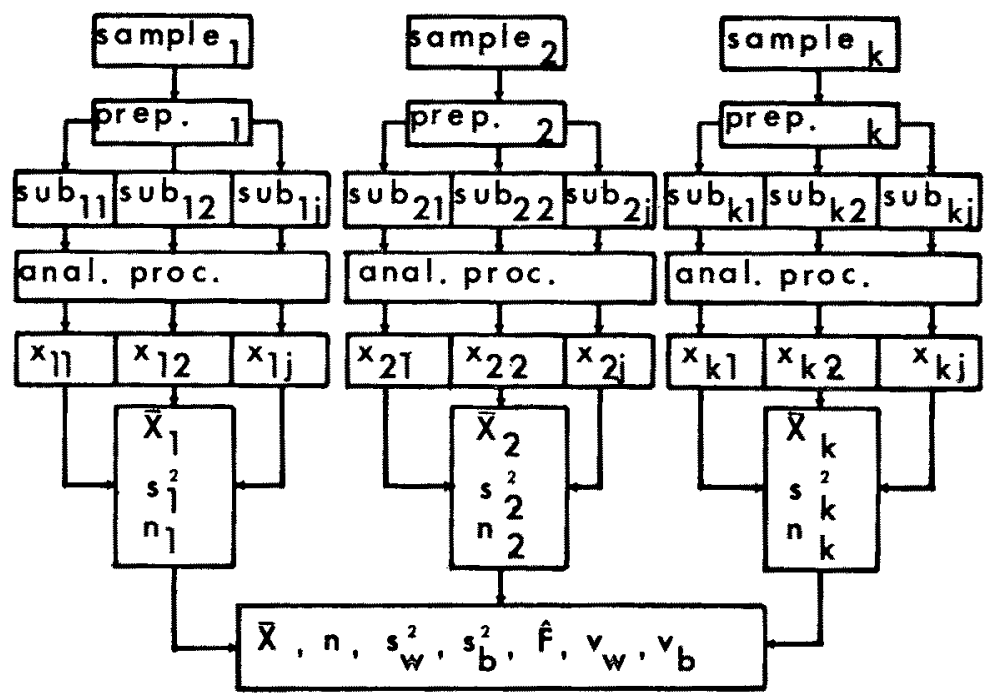

Fig. 1: Diagram of the preparation of the samples and the statistical analysis. Mathematical equations according to Sachs (1973, chapter 73 ). sample $1: 2, \mathrm{k}:$ sample consisted of organisms either taken from the same locality at time $1: 2, \mathrm{k}$ or from locality $1,2 . \mathrm{k}$ at comparable times; prep.: preparation of the samples (cleaning, freezing or freezc-drying); subii: subsamples consisted of several to hundreds individuals; anal. proc.: analytical procedure; $\mathrm{x}_{\mathrm{ii}}$ : Hg-concentration of one subsample; $\bar{x}_{i}$ : mean $\mathrm{Hg}$-concentration of one sample; $s^{3} i$ : variance of one sample; $n_{i}$ : number of determinations; $\bar{X}$ : weighted mean of all observations $-\frac{1}{n} \sum_{i}^{k} n_{i} \cdot \bar{x}_{i}$;

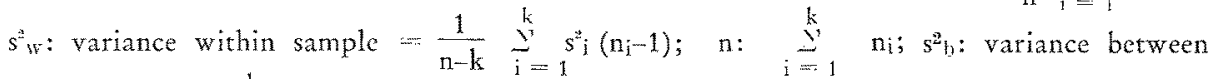
samples $=\frac{1}{k-1} \sum_{i}^{k} n_{i}\left(\bar{x}_{i}-\bar{X}\right)^{2} ; F:$ quotient of variances $=s^{2} b: s^{2} ; ; v_{W}$ : degree freedom $=\mathrm{n}-\mathrm{k} ; \mathrm{v}_{\mathrm{b}}$ : degree of freedom $=\mathrm{k}-1$ 


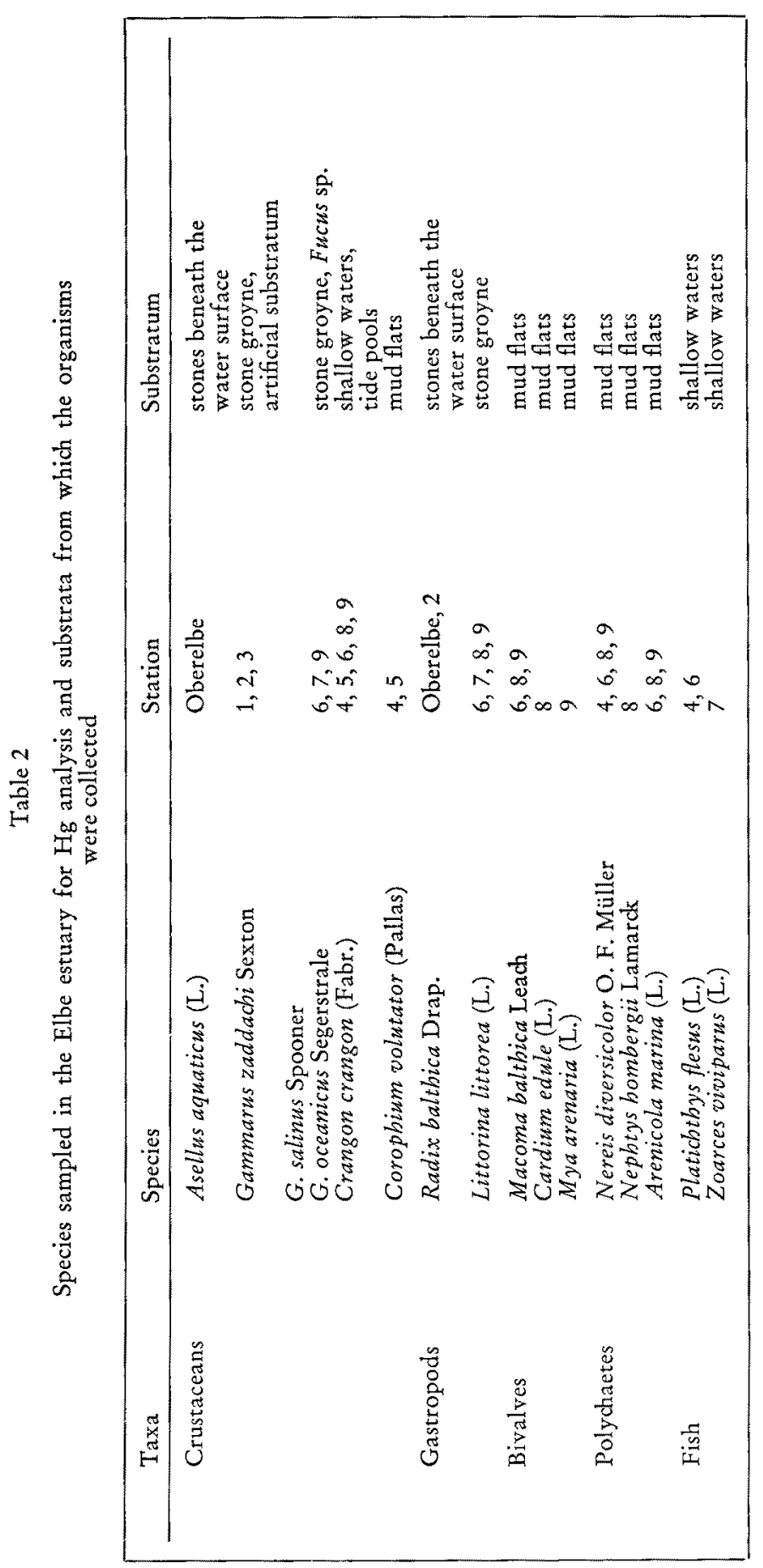




\section{METHODS}

\section{Preparation of the samples and statistical analys is}

After collection the organisms were washed at the sampling site. The gastropods and bivalves were kept in water from the sampling site for $48 \mathrm{~h}$, the polychaetes were kept under wet filter paper for $24 \mathrm{~h}$ to allow purging. After that the samples were stored frozen at $-18^{\circ} \mathrm{C}$. All other organisms were frozen immediately after sampling. Only the soft parts of gastropods and bivalves were used for Hg determination. In the case of all other organisms the whole body was prepared for further analysis. The samples were analyzed either as wet material or after freeze-drying, which was carried out for $48 \mathrm{~h}$ at $-25 \mathrm{C}$ and a pressure of approximately 0.5 torr above the ice.

A diagram of the preparation of the samples and the statistical analysis is given in Figure 1. The analysis of variance was carried out according to Sachs (1973, chapter 73). The null hypothesis of equality of means is to be rejected, if the quotient of variances $(F)$ exceeds a tabulated value $F$ which is depended on the level of significance (in this paper the $5 \%$ level) and the derrces of frecdom (Sachs, 1973)\%. Thus the mercury levels of given specics taken at different times from one locality were tested as well as the levels of given species taken from different localities.

\section{Analytical procedure}

$\mathrm{Hg}$ was analyzed by wet digestion (using mixtures of $\mathrm{HNO}_{3,} / \mathrm{H}_{2} \mathrm{SO}_{4}$ and $\mathrm{HNO}_{3 /}$ $\mathrm{HClO}_{4}$ ) and flameless atomic absorption spectrophotometry (AAS) as outlined by Antonacopoulos (1974), using a Coleman MAS-50 or a Perkin-EImer AAS-300. The element concentrations of 13 subsamples were determined by instrumental neutron activation analysis (INAA). Irradiation of the freeze-dried samples and gammaspectroscopy was done at the reactor station of the GKSS at Geesthacht (FRG). The integral flux of neutrons proved to be $8 \cdot 10^{18} \mathrm{n} / \mathrm{cm}^{2}$ (for details see Zauke, 1975). Only the results obtained for $\mathrm{Hg}$ will be discussed in this paper.

\section{Comparison of results obtained by different procedures}

A comparison of the results of the $\mathrm{Hg}$ analysis by AAS and INAA is shown in Figure $2 \mathrm{~A}$. The potential systematic errors of the analytical methods used are quite different. The fact that both methods yield nearly identical Hg values indicates that a bias in the analytical procedures (starting after freeze-drying) is quite unlikely. A

\footnotetext{
* This procedure presumes normal distributed values. The $\mathrm{Hg}$ values obtained for Littoria littorea collected in May-September were tested according to Sachs (1973, p. 252) as an example. There is no objection to the normal distribution hypothesis on the $10 \%$-level of significance $\left(\gamma^{2}=10.49<\chi^{2} 10 \%=14.68\right)$.
} 
comparison of values obtained by AAS using either wet or dry material is given in Figure $2 \mathrm{~B}$. Data are converted to $\mathrm{ppm}$ wet weight. In this case statistical parameters also indicate good agreement of results from both procedures. Therefore, a bias introduced by freeze-drying is not significant as is pointed out by La Fleur (1973), who found maximum errors of $5 \%$ being introduced by freeze-drying.
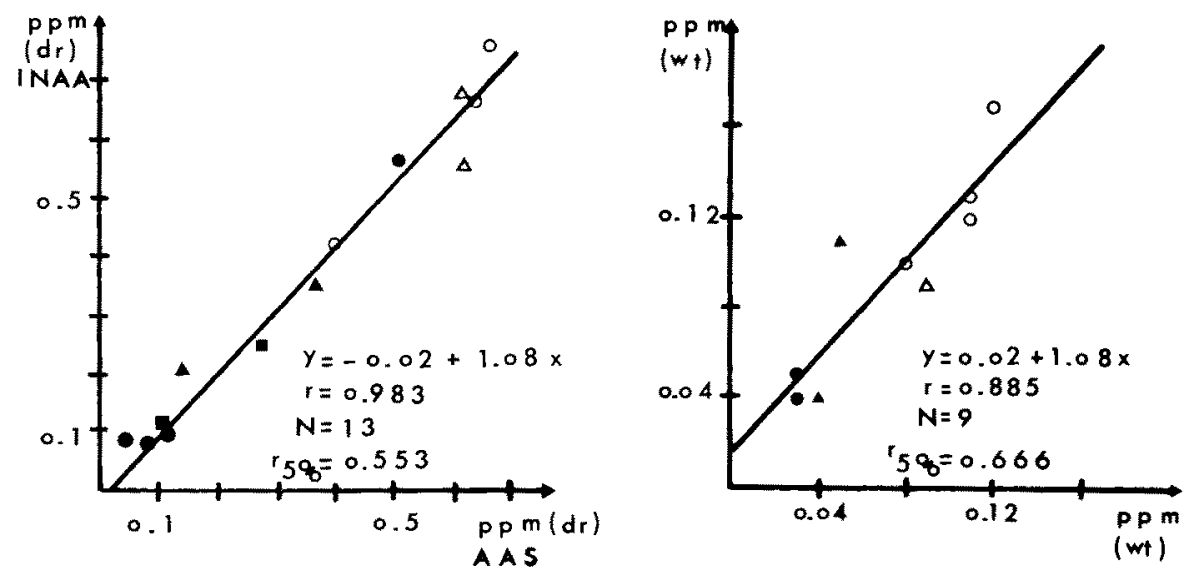

Fig. 2: Correlation analysis: comparison of analytical procedures. (A) $\mathrm{Hg}$ determination in benthic invertebrates from the Elbe estuary performed by atomic absorption spectrophotometry, AAS, ( $\mathrm{x}$-axis) and instrumental neutron activation analysis, INAA, ( $y$-axis). Values given in ppm (dry weight). (B) $\mathrm{Hg}$ determination carried out by AAS using wet ( $\mathrm{x}$-axis) and dry (y-axis) material. Data converted to ppm (wet weight). Symbols: $O$ Littorina littorea, Nereis diversicolor, $\triangle$ Corophinm volutator, $\boldsymbol{\Delta}$ Crangon crangon, gammarids. In both cases the correlation coefficients $\mathrm{r}$ are significant at least on the $5 \%$-level as they exceed tabulated values $r \%$ which are dependent on the degrees of freedom (Sachs, 1973; $\mathrm{p}, 330$ )

Furthermore, as the analysis of the freeze-dried material was carried out several months later, together with the samples taken in October and November, it is evident that the procedure yielded constant values over the period of investigation. This fact will be important when discussing the possibility of seasonal fluctuations (see below).

\section{RESULTS AND DISCUSSION}

\section{Hg concentrations in invertebrates from the Elbe estuary}

The results obtained by the procedures described are presented in Tables $3-7$ and are summarized in Figure 3 for some important organisms. All $\mathrm{Hg}$ concentrations are given in ppm wet weight unless otherwise indicated.

Some of the obtained $F$ values for Littorina littorea ( $c$, e, g, Table $3 b$ ) indicate different $\mathrm{Hg}$ levels in samples taken in July and October/November at nearly all stations, which might be interpreted as seasonal fluctuation. Assuming this, $\mathrm{Hg}$ concentrations tend to decrease from spring and summer to late autumn. 
Mercury in benthic invertebrates
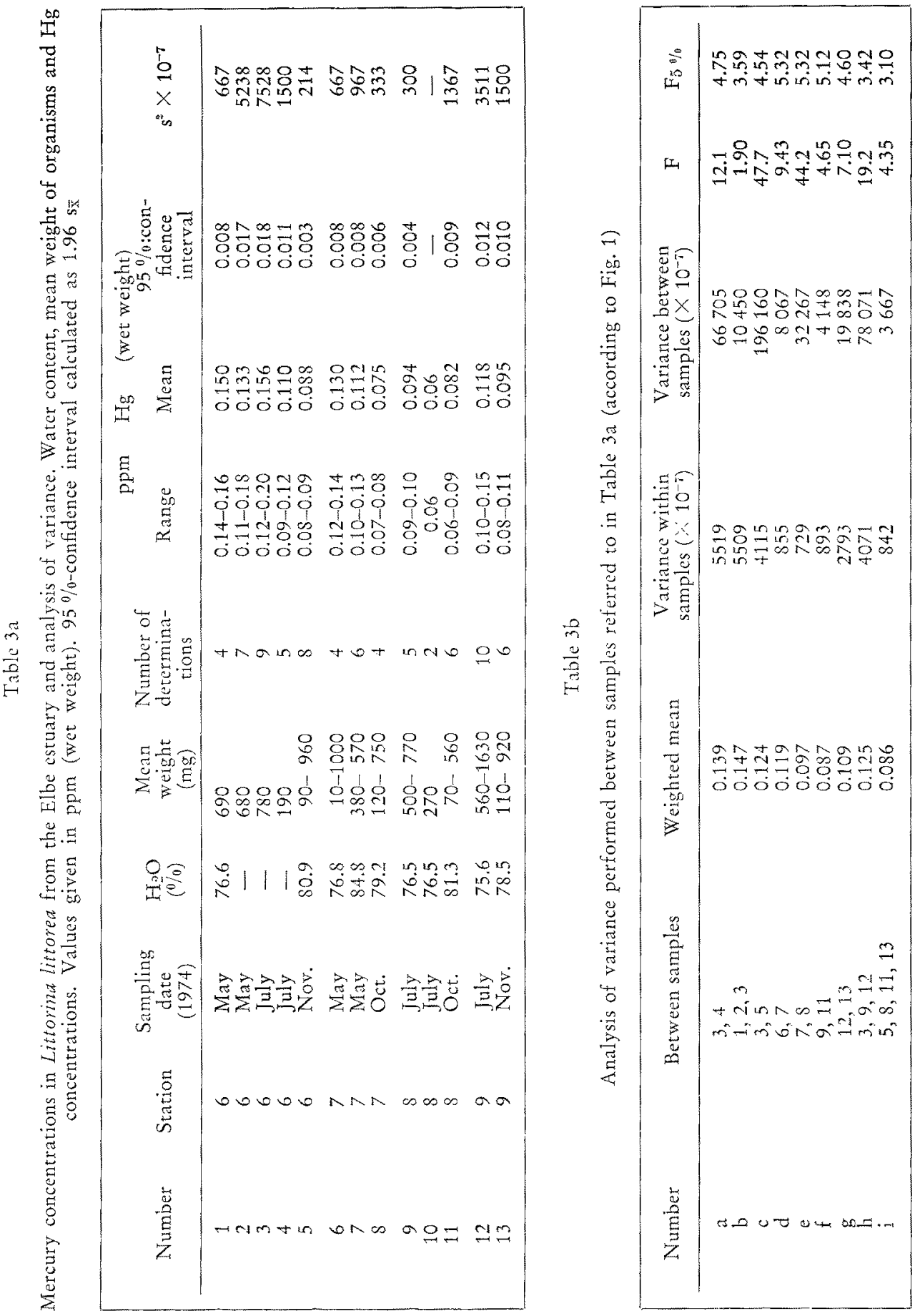

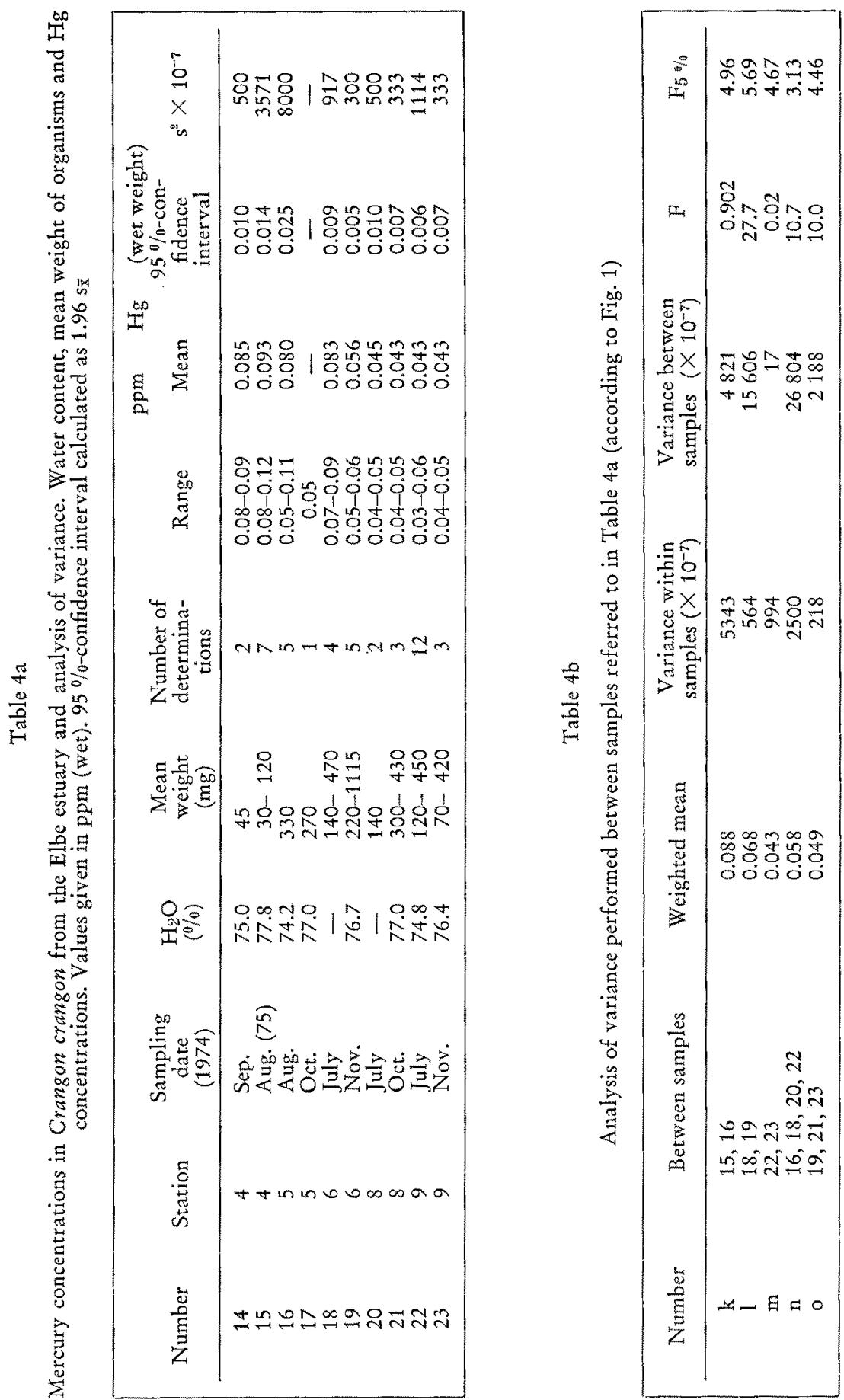
Mercury in benthic invertebrates

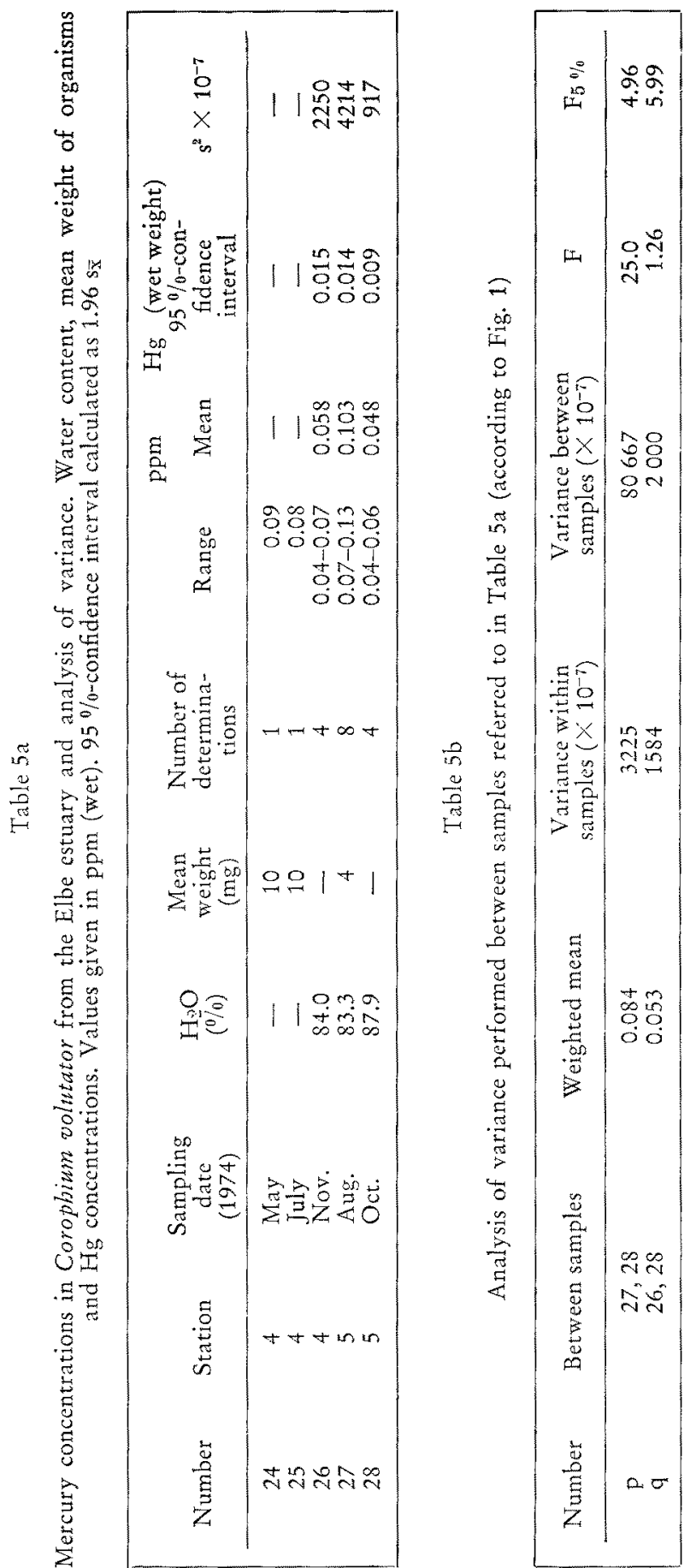




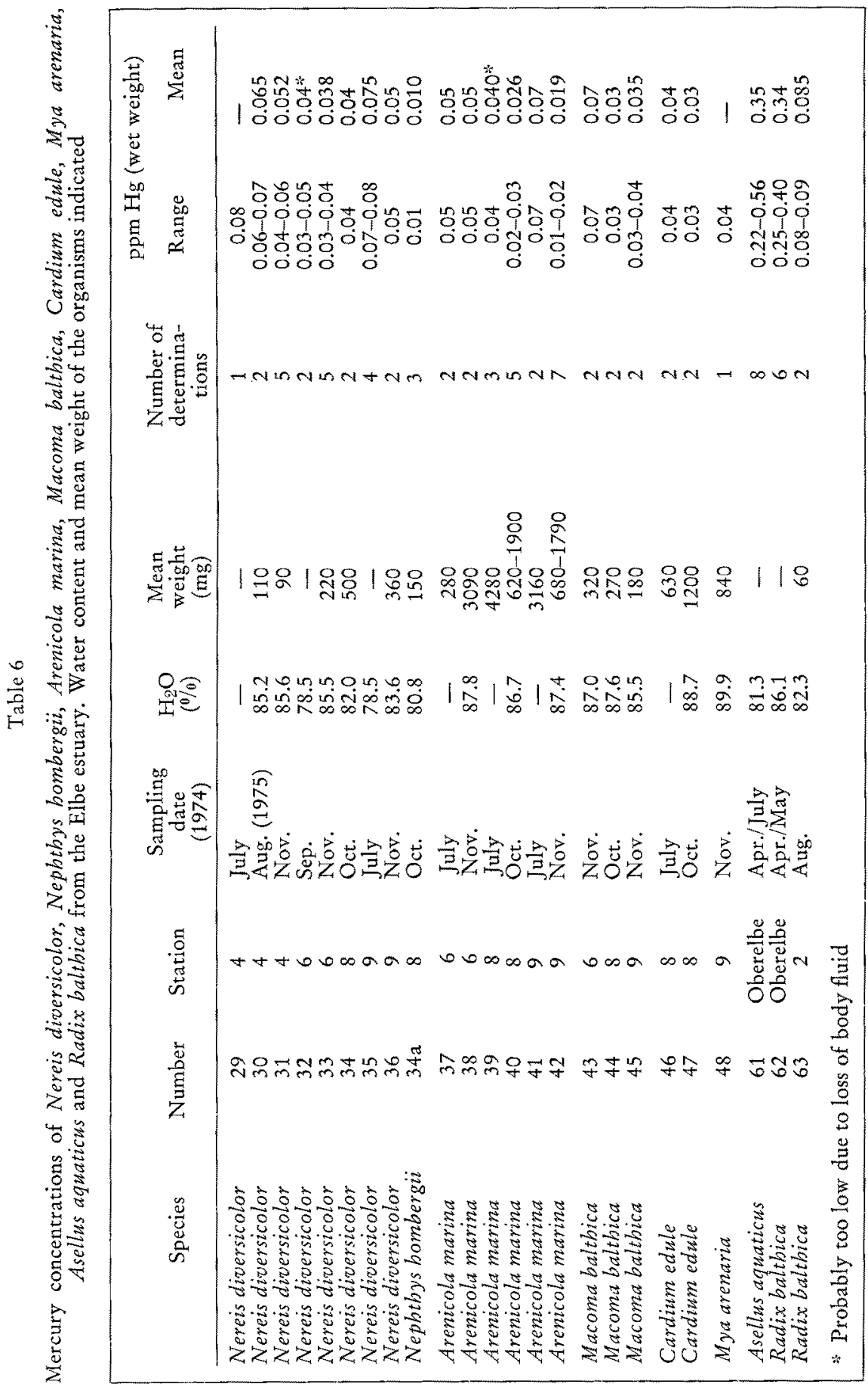


Mercury in benthic invertebrates
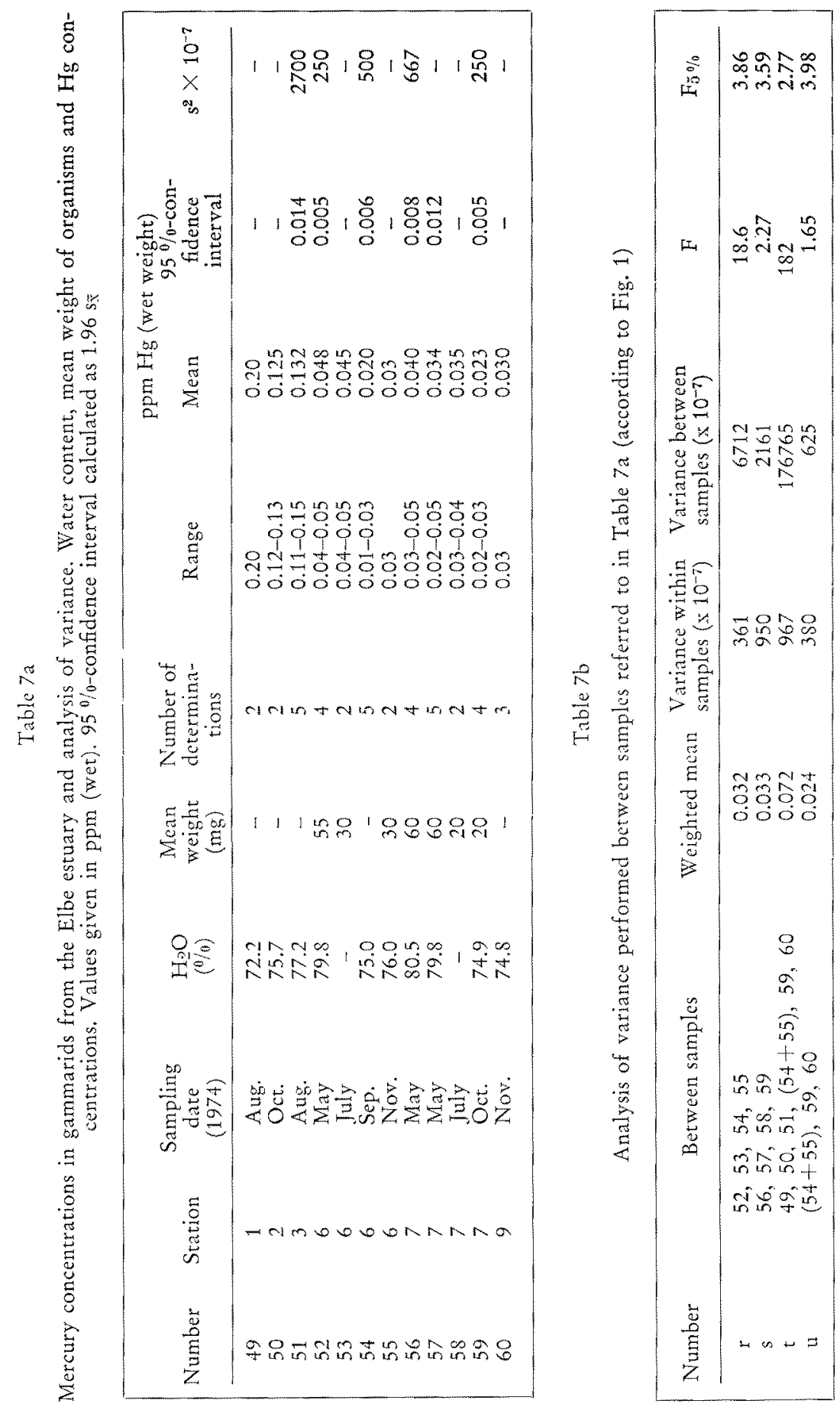


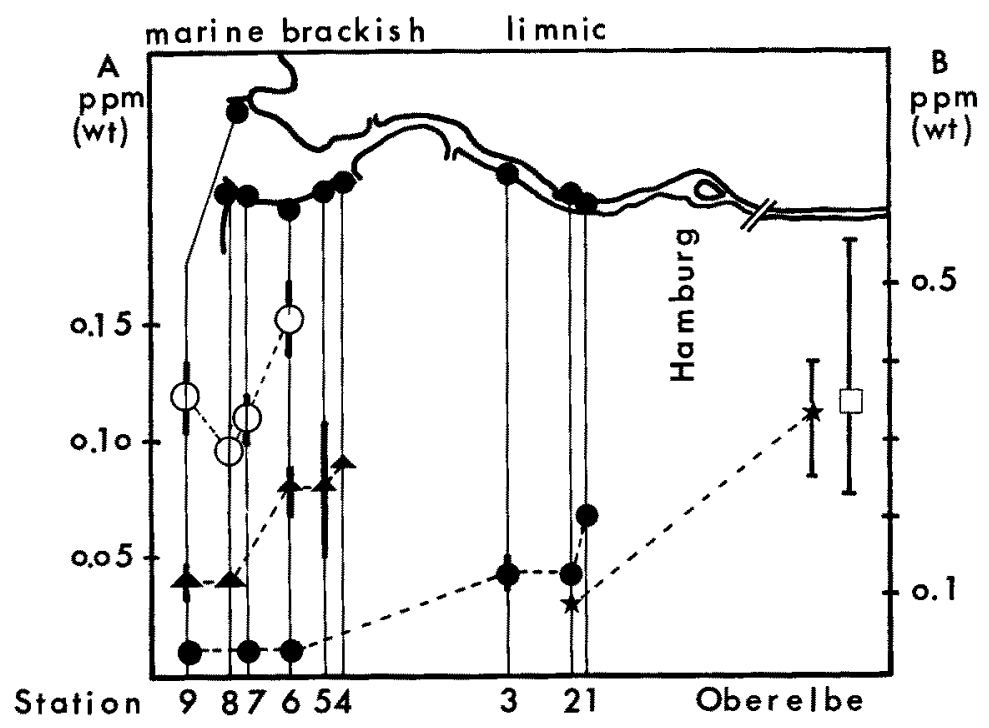

Fig. 3: Mean Hg concentrations of some important invertebrates from the Elbe estuary collected in May-September (see Tables 3-7). Values given in ppm (wet weight) for: (A) $\bigcirc$ Littorina littorea, $\mathbf{A}$ Crangon crangon, (B) $\square$ Asellus aquaticus, $\star$ Radix balthica, gammarids. $195 \%$-confidence interval $=1.96 \mathrm{~s}_{\overline{\mathrm{x}}} ; \mathrm{I}$ range

This also seems to be true for Crangon crangon from Station 6 (1, Table $4 \mathrm{~b}$ ), Corophium volutator from Station 5 ( $\mathrm{p}$, Table $5 \mathrm{~b}$ ) and gammarids from Station 6 ( $r$, Table $7 b$ ). In other cases lack of significance might be either due to low number of observations and appreciable variance within a sample or to the fact that no seasonal fluctuation occurs. From other $\mathrm{F}$ values it may be concluded that $\mathrm{Hg}$ concentrations differ when considering various localities. In general it can be seen that $\mathrm{Hg}$ levels in benthic invertebrates tend to decrease from the region upstream of Hamburg to the marine environment (Stations 8 and 9). This is demonstrated by the values for Radix baltbica and Asellus aquaticus sampled upstream of Hamburg and found to have relatively high amounts of $\mathrm{Hg}(0.34$ and $0.35 \mathrm{ppm}$ respectively, see Table 6$)$, as well as by the results for gammarid species which tend to decrease from the limnic region (Station $1,0.20 \mathrm{ppm}$ ) to the brackish and more marine environments $(0.02-0.05 \mathrm{ppm}$; $t$, Table $7 b$ ). This tendency is also apparent within the brackish region when considering the results for Littorina littorea ( $h$, Table $3 b$ ) and Crangon crangon ( $\mathrm{n}$, Table $4 \mathrm{~b}$ ) collected in summer, but not for gammarids ( $u$, Table $7 \mathrm{~b}$ ). On the other hand, this tendency is not so conspicuous in organisms collected in October/November. In the case of Littorina littorea even a slight change toward a more marine environment (Station 9) may be concluded (i, Table $3 \mathrm{~b}$ and o, Table $4 b$ ).

The geographical distribution of $\mathrm{Hg}$ in crustaceans (Asellus aquaticus and gammarids) is similar to that of the clay fraction of the sediment (analyzed by Müller \& Förstner, 1975), which may reflect the actual presence of $\mathrm{Hg}$ in this ecosystem (Table 8). 
Table 8

Relative $\mathrm{Hg}$ levels in the clay fraction of the sediments and in the crustaceans (Asellus aquaticus and gammarids) from the Elbe estuary. Values calculated by setting data of Müller \& Förstner (1975) and from Table 6 and 7 obtained for the brackish region as one. Regions: $\mathrm{a}=$ Oberelbe, $\mathrm{b}=$ Hamburg (station 1), $\mathrm{c}=$ lower limnic region (station 2, 3), $\mathrm{d}=$ brackish region (station 6,7 )

\begin{tabular}{|ccccccccc}
\hline Regions & $\mathrm{a}$ & & $\mathrm{b}$ & & $\mathrm{c}$ & & $\mathrm{d}$ \\
\hline Sediment $(<2 \mu \mathrm{m})$ & 14 & $:$ & 5 & $:$ & 3 & $:$ & 1 \\
Crustaceans & 12 & $:$ & 7 & $:$ & 4 & $:$ & 1 \\
\hline
\end{tabular}

Mercury contamination of the Elbe estuary as compared with other localities

The mean $\mathrm{Hg}$ concentrations of invertebrates from the Elbe estuary are summarized in Table 9 and compared with results reported from other localities (see Table 9 for references).

Information on the $\mathrm{Hg}$ contamination of fresh water benthic invertebrates is very scarce. Only unspecific data are available. Hg levels in organisms from the River Elbe seem to be somewhat higher than results from Clay Lake (Ontario, Canada) which was contaminated by the effluents of a chlorine alkali plant (Armstrong \& $\mathrm{Ha}$ milton, 1973) or a Swedish freshwater biotope situated above a paper mill (Johnels et al, 1967). On the other hand these values are markedly lower than those in organisms from sites below the paper mill effluent.

In the brackish region of the Elbe estuary, as is apparent in Table 9, Hg levels in organisms are generally of the same order of magnitude as reported for other localities. As for Littorina, only results from the Tay Region (Great Britain) and the Fjord of Kiel (Baltic Sea) seem to be somewhat lower, On the other hand, $\mathrm{Hg}$ levels in Crangon crangon from some British waters and from the Mediterrancan Sea tend to be higher. In the case of the Mediterranean Sea the effluents of a titanium dioxide plant are suspected to be of some significance (see Table 9).

The results of this comparison of organisms from the limnic region of the River Elbe show a sliyhtly increased $\mathrm{Hg}$ level, a fact that corresponds with the findings of Förstuer \& Müller (1974) when comparing the clay fraction of sediment in important German rivers. Moreover, Müller \& Förstner (1976) pointed out that the Hg levels of the sediment at Stade (limnic region) increased by a factor of 3 from 1973 to 1975 . It is obvious that further investigation is required, especially when one considers that the sources of the present $\mathrm{Hg}$ levels are unknown and that on the other hand an intensive process of industrialization is going on in this region which may contribute to further contamination. 


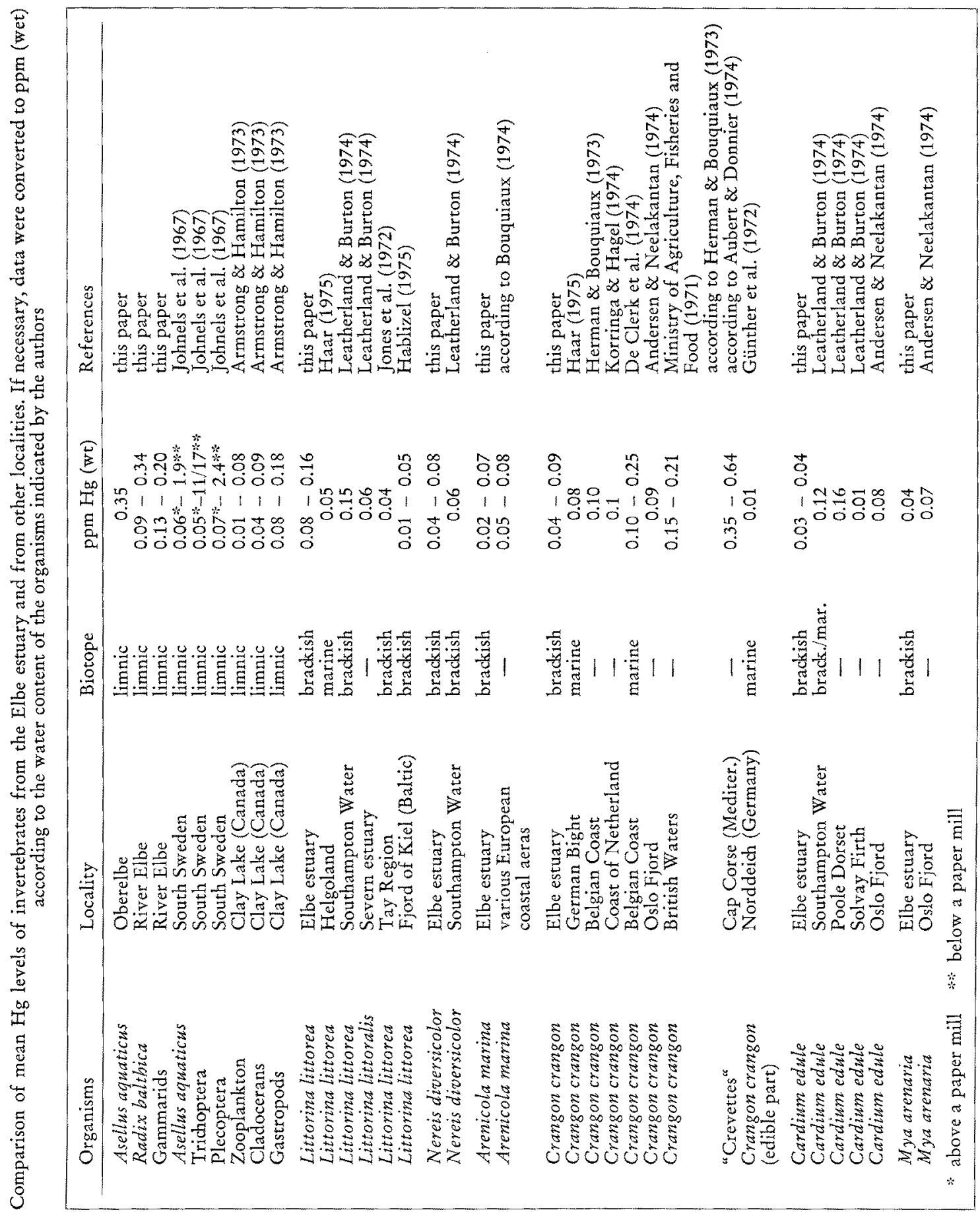




\section{Discussion of factors which may influence mercury concentrations in aquatic invertebrates}

From the results obtained in this investigation (some of which only are of preliminary character) the following factors will be discussed: (a) position of organisms in aquatic food chains, (b) weight of organisms, (c) elimination e. g. via moulting products in the case of crustaceans.

\section{Food chain}

Several of the invertebrates from the brackish region which were analyzed can be seen as components of brackish water food chains. For example, Coropbium volutator, Nereis diversicolor and to some extent gammarids are important food items of Crangon crangon (Tiews, 1967), in turn Crangon crangon is regarded as a relevant food source for various fishes (Kühl, 1961). Hg levels in these organisms are summarized in Figure 4.

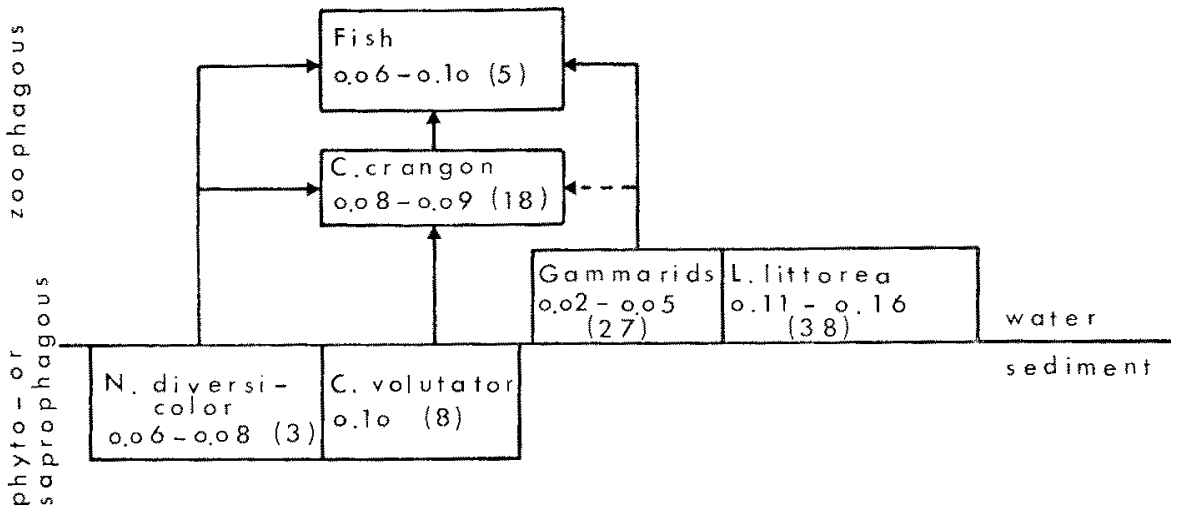

Fig. 4: Mean Hg levels in organisms of a bradish water food chain from the Elbe estuary. Samples taken in May-September at Stations 4-7 (see Tables 3-7). Values given in ppm (wet weight), (i) indicates number of determinations

From this figure it can be seen that $\mathrm{Hg}$ concentrations appear to be of the same order of magnitude in all trophic levels (but it should be kept in mind that only a few samples of small fishes, young Platichthys flesus and Zoarces viviparus, were analyzed). Only the concentrations of $\mathrm{Hg}$ in gammarids tend to be somewhat lower. The highest levels observed occur in individuals of the phytophagous snail Littorina littorea.

Data from the Wadden sea (The Netherlands) reported by de Goeij et al. (1972, according to van Genderen, 1974) are in good agreement with the preliminary results presented here. They found similar $\mathrm{Hg}$ contamination in invertebrates and fish. This also proved to be true for marine pelagic food chains, as reported by Leatherland et al. (1973), who found equal $\mathrm{Hg}$ levels in fish, some copepods and euphausids. Regarding other heavy metals, the concentrations of $\mathrm{As}, \mathrm{Cd}, \mathrm{Sb}$ and $\mathrm{Zn}$ analyzed by the same authors even tend to decrease from plankton to fishes of higher trophic levels. Such depletion of $\mathrm{Zn}$, As and $\mathrm{Cu}$ in the food chain was also reported by Windom et al. (1973) as regards marine pelagic fishes. 
On the other hand, data from Armstrong \& Hamilton (1973) and Bligh (1971), regarding limnic ecosystems, can either be interpreted as increased $\mathrm{Hg}$ accumulation in higher trophic levels or in benthic organisms as compared with pelagic species. Results from Potter et al. (1975) indicate increasing Hg concentrations in a limnic food chain. Jernelöv \& Lann (1971) calculated that only a minor part of the $\mathrm{Hg}$ (less than $25 \%$ ) was transferred from bottom fauna to bottom feeding fish, the major amount being accumulated directly from the water.

\section{Weight of organisms}

As mentioned above, some of the material was analyzed for correlations between $\mathrm{Hg}$ concentrations and mean weight (w) of the organisms. In two cases correlations were found to be significant (Crangon crangon: $\mathrm{ppm} \mathrm{Hg}=0.032+0.060 \mathrm{w}, \mathrm{N}=6$, $\mathrm{r}=0.996, \mathrm{r} 5 \%=0.811$; Littorina littorea: ppm $\mathrm{Hg}=0.091+0.094 \mathrm{w}, \mathrm{N}=10$, $r=0.913, r 5 \%=0.632$; see also a, Table 3).

Correlations between the heavy metal concentrations of aquatic invertebrates and their size or weight have been reported by several authors, e. g. Armstrong \& Hamilton (1973), Bryan \& Hummerstone (1973) and Leatherland \& Burton (1974). The heavy metal concentration may either increase or decrease with size or weight of the organisms, depending on the species and heavy metal in question. Therefore any data should be characterized by the weight or size of the organisms analyzed to allow comparison of results from various sources.

\section{Elimination via moulting products}

The $\mathrm{Hg}$ concentrations in moulting products of Crangon crangon have been analyzed in two cases and were found to be about $17 \%$ of the value which was obtained for the entire body, a fact which is almost in agreement with results (about $12 \%$ ) of Herman \& Bouguiaux (1973).

The $\mathrm{Hg}$ concentrations in carapaces of crayfish were found to be $12 \%$ (Armstrong \& Hamilton, 1973) and 19\% (Johnels et al., 1967) of the abdominal muscle, also indicating that an appreciable amount of $\mathrm{Hg}$ is accumulated in the skeleton of crustaceans. Fowler et al. (1971) observed an important transfer of radionuclides via moulting products of euphausids. Furthermore, the rate of elimination depends on the way in which the substances have been introduced into the animals. For instance, $0.3-2 \%$ of the $\mathrm{Zn}-65$ which has been accumulated in experiments is eliminated when it had been introduced by contaminated food, whereas about $18 \%$ is eliminated when it had been introduced by contaminated water.

It can be concluded from these findings that a decontamination of heavy metals may occur in crustaceans such as Crangon crangon or gammarids due to moulting. It may be possible that the relatively uniform $\mathrm{Hg}$ levels in Crangon crangon reported from several localities (see Table 9) are influenced by this fact. This effect is probably intensified by migrations of Crangon crangon into deeper waters in winter (Tiews, 1967), where concentrations of $\mathrm{Hg}$ are lower. 
Acknowledgements. This investigation was carried out at the University of Hamburg with financial support by the DFG (Deutsche Forschungsgemeinschaft) and was attended by Dr. L. Karbe. The $\mathrm{Hg}$ analysis by AAS was done at the Bundesforschungsanstalt für Fischerei, Hamburg, under the guidance of Dr. N. Antonacopoulos. The multielement analysis by INAA was performed at the reactor station of the Gesellschaft für Kernenergie in Schiffbau und Schiffahrt, GKSS, Geesthacht, Germany, with the aid of Dr. C. Schnier. Finally, the author wishes to thank Mrs. S. Euteneuer, Hamburg, for correcting the English and Dr. R. Schäfer and Dr. J. Timm, University of Bremen, for critical remarks on the statistical analysis.

\section{LITERATURE CITED}

Andersen, A. T. \& Neelakantan, B. B., 1974. Mercury in some marine organisms from the Oslofjord. Norw. J. Zool. 22, 231-235.

Antonacopoulos, N., 1974. Bestimmung von Quecksilber in Fischen und Fischerzeugnissen I. Zur Methodik der Probenvorbereitung und der Messung durch flammenlose Atomabsorption (Kaltdampfverfahren). Chem. Mikrobiol. Technol. Lebensm. 3, 8-16.

Armstrong, F. A. J. \& Hamilton, A. L., 1973. Pathways of mercury in a polluted Northwestern Ontario Lake. Trace metals and metal-organic interaction in natural waters. Ann Arbor Sciencc Publ, 131-156.

Aubert, M. \& Donnier, B., 1974. Pollution du millieu marine par le mercure et le cadmium en Méditerranéc. In: Problems of the contamination of man and his environment by mercury and cadmium. Commission of the European Communitics, Luxembourg, 261-276, EUR 5075.

Bouquiaux, J., 1974. Mercury and cadmium in the environment; first results of an enquiry on a European scale. In: Problems of the contamination of man and his environment by mercury and cadmium. Commission of the European Communities, Luxembours, 23-46, EUR 5075.

Bligh, E. G., 1971. Mercury levels in Canadian Fish. In: Mercury in man's environment. Royal Society of Canada, Ottawa, 87.

Bryan, G. W. \& Hummerstone, L. G., 1973. Adaptation of the polychaete Nereis diversicolor to estuarine sediments containing high concentrations of zinc and cadmium. J. mar. biol. Ass. U. K. 53, 839-857.

Caspers, H., 1959. Die Einteilung der Brackwasserregionen in einem Aestuar. Archo Oceanogr. Limnol. 11 (Suppl.), 153-169.

Clerk, R. de, Vanderstappen, R. \& Vynkc, W., 1974. Mercury content of fish and shrimps caught of the Belgian coast. Ocean Mgmt 2, 117-126.

Förstner, U. \& Müller, G., 1974. Schwermetalle in Flüssen und Seen als Ausdruck der Umweltverschmutzung. Springer, Berlin, 225 pp.

Fowler, S. W., Small, L. F. \& Dean, J. M., 1971. Experimental studies on climination of zinc-65, cesium-137, and cerium-144 by euphausids. Mar. Biol. 8, 224-231.

Genderen, H. van, 1974. The pollution of surface waters by mercury and cadmium conpounds, the cffects on the fauna, and ccological pollution limits for fresh water. In: Problems of the contamination of man and his environment by mercury and cadmium. Commission of the European Communities, Luxembourg, 247-259, EUR 5075.

Goeij, J. J. M. de, Houtman, J. P. W., Tioe, P. S. \& Koeman, J. H., 1972. Mercury distribution levels obscrved in various ecosystems as determined by neutron activation analysis. Paper presented at the IAEA symposium on nuclear activation techniques in the life science, Bled (Yougoslavia). (Unpubl.).

Günther, F., Oostinga, I. \& Burckhart, O., 1972. Ober die Quecksilbergehalte in Sec- und Suißswasserfischen sowie in Krusten-, Muschel- und Säugetieren der ostfriesischen Küstenund Binnengewässer. Medizin Ernähr. 13, 263-267.

Haar, E., 1975. Schwermetallgehalte in Benthosorganismen aus den Wattengebicten der deutschen Nordseeküste; Beziehungen zum Schwermetallgehalt von Schwebstoffen und Sediment. Diplomarbeit, Universität Hamburg, $67 \mathrm{pp}$. 
Hablizel, H., 1975. Schwermetalle in Benthosorganismen der äußeren Kieler Förde; regionale Verteilung im Bereich der Abwassereinleitung Bülk. Diplomarbeit, Universität Hamburg, $101 \mathrm{pp}$.

Harms, U., 1974. Bestimmung der Obergangsmetalle Mangan, Eisen, Kobalt, Kupfer und Zink in Flußfischen mit Hilfe der Röntgenfluoreszenzanalyse und der flammenlosen Atomabsorption. Arch. FischWiss, 25, 63-74.

Herman, P. \& Bouquiaux, N., 1973. Study of the pollution in sea fish and shell fish. A. Rep. Belg. natn. R-D Progr. Envir. 3, 383-396.

Jernelöv, A. \& Lann, H., 1971. Mercury accumulations in food chains. Oikos 22, 403-406.

Johnels, A. G., Westermark, T., Berg, W., Persson, P. I. \& Sjöstrand, B., 1967. Pike (Esox lucius) and some other aquatic organisms as indicators of mercury in the environment. Oikos 18, 323-333.

Jones, A. M., Jones, Y. \& Stewart, W. D. P., 1972. Mercury in marine organisms of the Tay Region. Nature, Lond. 238, 164-165.

Karbe, L., Antonacopoulos, N. \& Schnier, C., 1975. The influence of water quality on accumulation of heavy metals in aquatic organisms. Verh. int. Verein. theor. angew. Limnol., 19, 2094-2101.

Korringa, P. \& Hagel, P., 1974. Mercury pollution, a local problem. In: Problems of the contamination of man and his environment by mercury and cadmium. Commission of the European Communities, Luxembourg, 279-293 (EUR 5075).

Kühl, H., 1961. Nahrungsuntersuchungen an einigen Fischen im Elbemündungsgebiet. Ber. dt. wiss. Kommn Meeresforsch. 16, 90-104.

La Fleur, P. D., 1973. Retention of mercury when freeze-drying biological material. Analyt. Chem. 45, 1534-1536.

Leatherland, T. M. \& Burton, J. D., 1974. The occurrence of some trace metals in coastal organisms with particular reference to the Solent Region. J. mar. biol. Ass. U.K. 54, 457-468.

- - Culkin, F., McCartney, M. J. \& Morris, R. J., 1973. Concentrations of some trace metals in pelagic organisms and of mercury in Northeast Atlantic Ocean water. Deep Sea Res. 20, 679-685.

Müller, G., 1976. Schwermetalle in den Sedimenten der Elbe bei Stade: Veränderungen seit 1973. Naturwissenschaften 63, 242-243.

- \& Förstner, U., 1975. Heavy metals in sediments of the Elbe-estuaries: mobilization or mixing effect? Envir. Geol. 1, 33-39.

Nauke, M., 1974. Die Schwermetallgehalte der Sedimente im Klärschlammverklappungsgebiet vor der Elbe-Mündung. Dt. hydrogr. Z. 27, 203-213.

Potter, L., Kidd, D. \& Standiford, D., 1975. Hg levels in Lake Powell: Bioamplification of mercury in man made desert reservoirs. Envir. Sci. Technol. 9, 41-46.

Sachs, L., 1974. Angew andte Statistik. Springer, Heidelberg, 248 pp.

Tiews, K., 1967. Crangon crangon. F. A. O. Fish. Rep. 54, 56-59, 1967-1970.

Windom, H., Stickney, R., Smith, R., White, D. \& Taylor, F., 1973. Arsenic, cadmium, copper, mercury, and zinc in some species of North Atlantic finfish. J. Fish. Res. Bd Can. 30, 275-279.

Zauke, G.-P., 1975. Untersuchungen über den Schwermetallgehalt in Benthos-Organismen aus den Halinitätszonen des Elbe-Astuars, durchgeführt unter Anwendung von flammenloser Atomabsorption und instrumenteller Neutronenaktivierungsanalyse. Diplomarbeit, Universität Hamburg, $113 \mathrm{pp}$.

Author's address: G.-P. Zauke

Universität Bremen

Studienbereich Biologie

Postfach 330440

D-2800 Bremen

FRG 